\title{
Pointer years and growth in Turkey oak (Quercus cerris L) in Latium (central Italy). A dendroclimatic approach
}

\author{
M Romagnoli, G Codipietro \\ Dipartimento di Scienze dell'Ambiente Forestale e delle sue Risorse, \\ Universitá della Tuscia, 01100 Viterbo, Italy
}

(Received 2 November 1994; accepted 1 November 1995)

\begin{abstract}
Summary - A dendrochronological and a dendroclimatological analysis was carried out on samples of Turkey oak from seven sites in Latium. This research was effected in order to investigate what climatic impulse makes the dendrochronological curves of different sites comparable to each other. The Latium region proved particularly suitable for this kind of analysis due to its many orographic, climatic and pedologic differences within distances of a few kilometres. Pointer years were checked on the residuals curves and on the raw data taking into account the same growth trend for consecutive years. The dendroclimatic analysis showed that the majority of pointer years are related to spring precipitation and to June temperature. In addition, a preliminary approach is reported to define some anatomical features of pointer years. An automatic image analysis system was used to examine anatomical features in pointer years and a new method for histological quantitative representation is proposed.
\end{abstract}

dendroclimatology / Quercus cerris / pointer year / image analysis

Résumé - Années caractéristiques et accroissement du chêne chevelu (Quercus cerris $L$ ) dans le Latium (Italie centrale). Une approche dendroclimatique. Une analyse dendrochronologique et dendroclimatologique a été menée sur quelques échantillons de Quercus cerris prélevés dans sept sites du Latium. L'objectif majeur de l'analyse est d'identifier les facteurs climatiques qui rendent comparables entre elles les courbes dendrochronologiques correspondant aux différents sites prospectés. La région prospectée fournit des situations orographiques, pédologiques et climatiques variables sur de courtes distances. Les années caractéristiques sont déterminées par l'analyse des tendances de croissances communes. II résulte de l'analyse dendroclimatique que la plupart des années caractéristiques sont en relation directe avec les précipitations de printemps et en relation inverse avec les températures de juin. Par ailleurs, un premier essai de caractérisation anatomique des années caractéristiques par analyse d'image a été réalisé et une nouvelle méthode de description histologique quantitative a été testée. 


\section{INTRODUCTION}

Among the deciduous Quercus, the species robur, petraea and pubescens are the most studied from a dendrochronological point of view. Numerous publications are available concerning the dendrochronology of Quercus robur and $Q$ petraea (see inter alia Pilcher et al, 1977, 1984) and the dendroclimatology of $Q$ robur, $Q$ petraea and $Q$ pubescens (cf Pilcher and Gray, 1982; Tessier, 1986; Bednarz and Ptak, 1990).

Many dendrochronological curves have been established for both dating purposes and also for regional and more expanded interests. Some of the curves range back over many centuries because of the innate durability of these species (Pilcher et al, 1977, 1984).

However, in just the past few years, dendrochronological analysis has been effected in Italy on $Q$ cerris, an oak belonging to the taxonomic section cerris (Schirone and Romagnoli, 1990; Romagnoli, 1993; Corona et al, 1994; Martinelli et al, 1994). The species range is limited to central southern Europe, but it is present particularly in the Italian and Balcanic Peninsula and it may also be found in central East Asia. From an anatomical point of view, $Q$ cerris is a porous ring species and, like other species belonging to the cerris section, it shows gradual transition from earlywood to latewood. Vessel diameter is larger than that measured in the suber taxonomic section. Latewood vessel frequency is less than that in the section robur species.

From a dendroclimatological viewpoint, some results relative to the same species were previously obtained in Syria (Chalabi and Serre-Bachet, 1981) and articles dealing with the same subject have been published by Janous and Bartak (1991), Jaro and Tatraaljai (1984), Babos (1986) and Raev and Georgiev (1985) in the Balcanic region.
Currently, the dendrochronological curves of Turkey oak in Italy span only one or two centuries with the exception of some specimens found in Sicily. This can be attributed to either Italian forestry activities, meaning that Turkey oak, often found in coppice stands, is frequently subjected to cutting, or to poor durability of the species (Corona, 1988, 1989).

Deciduous oaks, Turkey oak included, are sensitive to the environment and are characterized by homogeneous dendrochronological behaviour covering large areas. Thus, they record the same climatic impulse at different latitudes (Corona, 1987, 1989 ) and in different ecological circumstances.

This characteristic initiated the search for those common climatic factors which might determine the common behaviour of different populations of the same species. The Latium region proved particularly suitable for this kind of analysis due to its numerous orographic, climatic and pedologic differences within distances of a few kilometres.

\section{MATERIALS AND METHODS}

\section{Study area}

Although from a climatic point of view, the Latium region (central Italy) is characterized by Mediterranean rainfall distribution (ie, minimum rainfall during summer months and maximum during autumn), the area under investigation shows variable drought and cold stress periods. The specimens stand in soils which have different degrees of fertility and depth. Some characteristics of the evaluated area are reported in table I (for further details, cf Blasi, 1994).

Turkey oak is the most common deciduous oak found in the landscape we studied. It grows in pure or mixed stands with occasional elements of Holm oak ( $Q$ ilex) and cork-oak woods ( $Q$ suber) (sites $3,4,5,6,7$ ) but most often with pubescent oak ( $Q$ pubescens). Where water table 
Table I. Brief description of sites. Mitrakos indices (from Blasi, 1994).
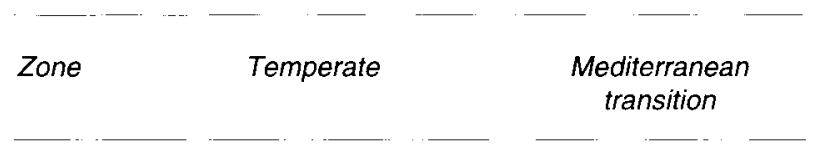

\section{Mediterranean}

$\begin{array}{lc}\text { Site } & 1-2 \\ \text { SDS } & 0-77 \\ \text { YDS } & 0-77 \\ \text { WCS } & 168-219 \\ \text { YCS } & 267-369 \\ \text { Soil } & \text { Vulcanic }\end{array}$

$$
\begin{gathered}
3-4-5 \\
55-137 \\
55-137 \\
127-170 \\
108-270 \\
\text { Vulcanic, } \\
\text { clay and }
\end{gathered}
$$
pyroclastic rocks

$$
\begin{gathered}
6-7 \\
139-194 \\
194-240 \\
66-141 \\
79-210 \\
\text { Sandy }
\end{gathered}
$$

Pliocene clay, fluvial and lake drifts

SDS: summer drought stress; YDS: year drought stress; WCS: winter cold stress; YCS: year cold stress.

surfaces, Turkey oak can be found mixed with British oak ( $Q$ petraea).

Other differences between sites must be attributed to distance from the sea (cf fig 1); altitude, which spans from close to sea level (sites 6 and 7$)$ to $100-500 \mathrm{~m}$ asl (sites $2,3,4,5)$ to about $700 \mathrm{~m}$ asl in site 1; and to other particular microclimatic circumstances such as vicinity to a lake (sites 1 and 5).

\section{Samples}

Sixty-four Turkey oak trees were analysed (table II). Cores and disks were taken at breast height from dominant and codominant trees in high forests (sites $1,5,6,7$ ), from standards in coppice (sites 3 and 4 ) and either from isolated trees or from trees situated in marginal positions (site 2).

\section{Tree-ring data}

Identification of the common climatic factor acting on tree growth was effected by identifying 'pointer years' on dendrochronological curves (Schweingruber et al, 1990), and establishing the mean of tree ring to climate relationships through response functions (Tessier and Serre-Bachet, 1990). In addition, an image analysis approach was carried out to investigate whether particular microscopic characteristics such as vessel dis-
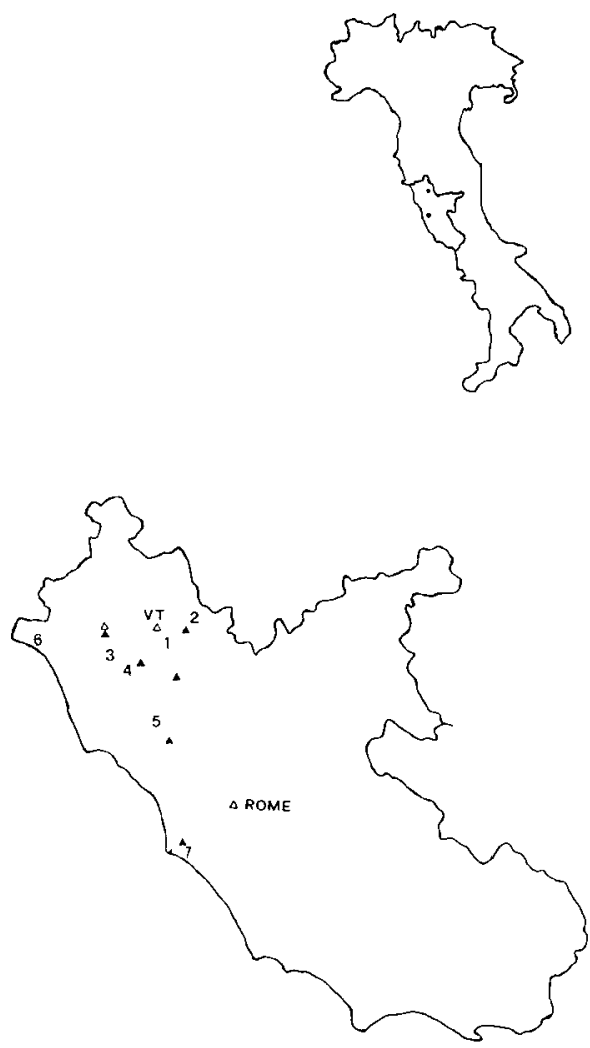

Fig 1. Location of the sites (1-7) and meteorological stations for the pluviometric series $(\boldsymbol{\Delta})$ and thermometric series $(\Delta) \mathrm{VT}$ : Viterbo town. 
Table II. Climatic parameters of the meteorological stations used to calculate response function.

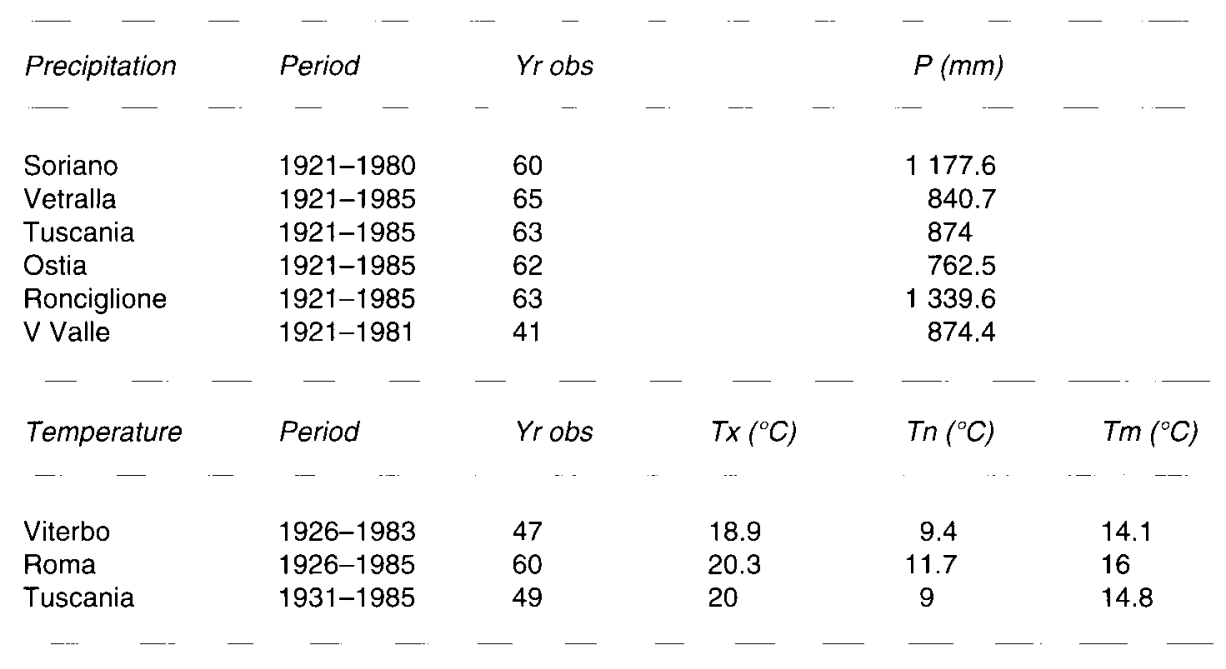

Yr obs: year observed; $P$ : total annual mean precipitation; Tx: annual maximum mean temperature; Tn: annual minimum mean temperature; Tm: annual mean temperature.

tribution (eg, one or three rows of vessels forming the porous ring part) corresponded to pointer years individuated by means of growth trend analysis.

\section{Dendrochronological curves and pointer years}

Ring widths were measured in units of $1 / 100 \mathrm{~mm}$ and the dendrochronological curves for each core were developed using Aniol's system (Aniol, 1983, 1987). Mean site chronologies were formed after verifying visual and statistical synchronization between the dendrochronological curves of individual trees. These site chronologies were then averaged to obtain a preliminary mean regional curve for the area. Each individual tree curve was standardized using Arma models (Guiot, 1986). The order of the Autoregressive and Moving Average model is determined by considering autocorrelation in series, at the same time excluding complicated models which are difficult to explain from the biological point of view (Tessier, 1986; Guiot, 1990; Nola, 1992; Corona et al, 1994). These procedures result in residuals without autocorrelation. Hence, seven site mean curves and a regional mean curve of the residuals were established.

Pointer years were checked on residual curves and raw data, taking $75 \%$ as the threshold for samples having the same growth trend for consecutive years (Huber and Giertz-Siebenlist, 1969; Trénard and Duchateau, 1985; Nola, 1992). Results are discussed referring to pointer years based on $75 \%$ of the total 64 samples and beginning with 1921 as the initial year of rainfall observation (table II).

Although the common growth trend among trees is often called pointer interval (Schweingruber et al, 1990), for the purposes of this research, it seems more appropriate to speak generally about pointer years as we do not wish to restrict the meaning of the present paper to the sole analysis of annual widths.

\section{Image analysis}

Intra-annular elements (vessel area and distribution) are investigated from five random samples collected in site 4 , characterized by chronologies which are very well correlated to each other and with climatic parameters as well. We exam- 
ined the 5 years spanning from 1950-1954 which are characterized by three pointer years (1951, 1952 and 1953).

Microscopic wood sections were prepared and observed using a stereomicroscope with a video camera. The picture taken by the camera, which corresponds to a real wooden surface of about $7 \mathrm{~mm}$ * $5 \mathrm{~mm}$, is digitized into a grid of pixels which are displayed on the computer screen. The digitized image may subsequently be stored.

The automated image-analysis system differentiates an object from the background by means of differences in levels of grey relative to the image pixels. The image analysers scan the memory for pixel data having intensity values greater than or less than certain threshold value set by the user, and they look at the number of such pixels, recognizing objects by selecting out groups of contiguous pixels.

A ring and an intraradial portion is delimited in each image (fig 2). The number of vessels is counted and, for each vessel, lumen area and the coordinates of the point closest to the ring boundary were recorded (fig 2 , raw vessel diagram).

A method of standardization was developed so as to compare different years, which have different ring widths, and to simplify the representation of vessel distribution down to ten elements. This system differs from that usually employed to obtain tracheidograms for coniferous trees (Vaganov, 1990; Codipietro, 1994). It consists in dividing the ring into ten equal segments and averaging the area values of the vessels originating in the same interval (fig 2, vessel dia. gram). The standardized vessel diagram shows vessel lumen variation within the ring and highlights such phenomena as stasis in the formation of the vessel lumen. The standardized series of the five samples were compared using mean values and standard deviation.

\section{Climatic data}

Climatic data were collected by the 'Annali del Servizio Idrografico del Ministero dei Lavori Pubblici'. Monthly precipitation, total annual precipitation, monthly maximum and minimum temperature and mean annual temperature from the meteorological stations located near the investigated sites were taken into account. Some meteorological series were, however, not included due to shortage of or missing data. The final climatic and dendroclimatic elaboration was carried out using the meteorological series which, following preliminary dendroclimatic analysis, produced the best results correlating with the dendrochronological data.

The main mean meteorological parameters (rainfall and temperature) of weather stations employed in this analysis are reported in table II.

Monthly temperature and precipitation series were arranged from October of the year $\mathrm{t}-1$ to September of the year $t$ (year of ring construction) (Serre-Bachet and Loris, 1988; Tessier, 1989; Messaoudene, 1989; Tessier and SerreBachet, 1990; Tessier et al, 1994) for the period of 1931-1985.

Monthly precipitation and monthly temperature of six and three metereological stations, respectively, were averaged to obtain an array of data which may be considered more representative of the regional climate of the investigated area. This matrix enables us to obtain better results during the processes of calibration and verification (Blasing et al, 1981) and in calculating the response function. Monthly precipitation data was combined with monthly maximum temperature and monthly minimum temperature data in order to form two arrays of 24 regressors ( $P$ TMAX, P-TMIN) for each meteorological station and for the averaged climatic regional parameters.

\section{Growth-climate relationship}

The growth-climate relationship was investigated in two phases. Pointer years marked on the residuals total mean curve were compared with annual mean climatic data arranged from October of year t1 to September of year $t$. Subsequently, a response function was calculated using the global array of climatic data as an independent variable and the mean total residual curve as a dependent variable. A response function for each site was also calculated using each residual curve as a dependent variable and the meteorological series of stations closest to the site examined as independent variables.

The response functions are estimated using the bootstrap method. This methodology was established by Guiot $(1990,1991)$ and is frequently applied to dendroclimatic analysis of deciduous oaks (Tessier, 1986; Messaoudene, 
1989; Tessier and Serre-Bachet, 1990; Nola, 1991, 1992; Santini et al, 1994; Tessier et al, 1994) and of the Turkey oak in particular (Schirone and Romagnoli, 1990; Romagnoli, 1993; Corona et al, 1994; Martinelli et al, 1994). The global statistical significance of a response function is expressed by the verification data set's multiple regression coefficient and standard devi- ation (Gadbin, 1992). Variance due to the climate derives from the multiple regression coefficient calculated on the calibration data set. The monthly growth-climate relationships are expressed by codes which are the ratio of the monthly partial regression coefficient and their standard deviation (Nola, 1991; Gadbin, 1992; Martinelli et al, 1994; Santini et al, 1994; Tessier et al, 1994).

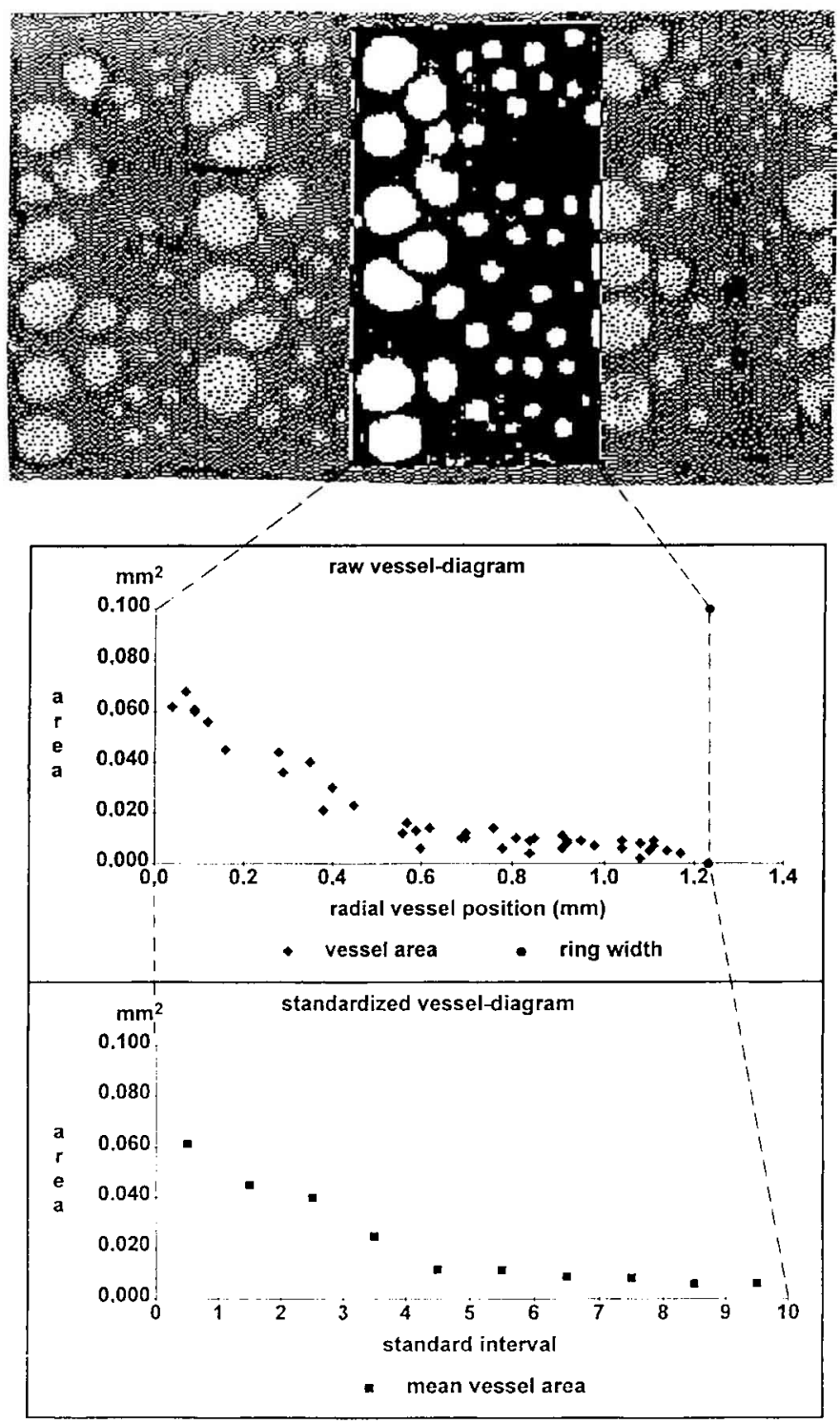

Fig 2. Examination of the image portion relative to the 1953 Vetralla 13 sample. Scanning supplies a series of data with which the raw vessel diagram may be built in function of the position along the ray of the vessel point closest to the beginning of the ring. Subdivision of the ring into ten equivalent segments permits attribution of each vessel to an interval (vessel diagram) and to calculate mean area values within each interval so as to otain the standardized vessel diagram. 
RESULTS

\section{Dendrochronological curves and pointer years}

The most important dendrochronological features of the curves examined are reported in table III. A mean dendrochronological curve was built consequent to visual verification (fig 3) and statistical agreement, the latter by coincidence coefficient tests (table IV) between the site curves.

The most important mean curve dendrochronological parameters are: mean value $2.87 \pm 1.28 \mathrm{~mm}$, autocorrelation coefficient 0.851 and mean sensitivity 0.161 .
Autocorrelation is an indicator of the inertness in tree growth and mean sensitivity indicates tree response to the environment and corroborates with the values which are generally considered characteristic for deciduous oaks (Corona, 1989).

The majority of pointer years coincides with the raw data and residuals data (fig 4) even if the percentage of the samples in which they appear is different. It must be noted that over the last 20 years, the number of pointer years has decreased.

There are more positive pointer years in the residuals than in the raw data, while the opposite is true for negative pointer years. It would be interesting to increase the number of samples to check repetition of this result. This could be connected with the

Table III. Dendrochronological features of site curves.

\begin{tabular}{llrrrl} 
Site & Period & SN & MxL & Mil & SeN \\
\hline & & & & & \\
1 & $1909-1991$ & 14 & 83 & 45 & 27 \\
2 & $1887-1991$ & 10 & 105 & 34 & 19 \\
3 & $1842-1985$ & 8 & 144 & 125 & 32 \\
4 & $1897-1988$ & 7 & 92 & 34 & 19 \\
5 & $1828-1989$ & 11 & 162 & 92 & 16 \\
6 & $1873-1991$ & 8 & 119 & 48 & 15 \\
7 & $1863-1990$ & 6 & 126 & 65 & 12 \\
\hline
\end{tabular}

SN: number of trees examined; MxL: number of rings of the longest series; Mil: number of rings of the shortest series; SeN: replication number.

Table IV. Statistical agreement. Coincidence coefficient values and $t$ values.

\begin{tabular}{|c|c|c|c|c|c|c|c|c|c|c|c|c|}
\hline \multirow[b]{2}{*}{ S1 } & \multicolumn{2}{|c|}{$S 2$} & \multicolumn{2}{|c|}{ S3 } & \multicolumn{2}{|c|}{ S4 } & \multicolumn{2}{|c|}{ S5 } & \multicolumn{2}{|c|}{ S6 } & \multicolumn{2}{|c|}{$S 7$} \\
\hline & 67.7 & 3.45 & 63.2 & 2.68 & 69.0 & 5.94 & 76.9 & 5.05 & 65.2 & 3.23 & 59.9 & 5.05 \\
\hline $\mathrm{S} 2$ & & & 67.9 & 5.19 & 65.6 & 4.36 & 70.6 & 5.16 & 63.5 & 4.57 & 67.0 & 4.51 \\
\hline S3 & & & & & 65.6 & 5.39 & 66.1 & 7.01 & 66.5 & 5.50 & 67.2 & 7.56 \\
\hline S4 & & & & & & & 72.9 & 7.93 & 62.9 & 4.35 & 66.1 & 4.24 \\
\hline S5 & & & & & & & & & 61.5 & 5.50 & 67.5 & 7.56 \\
\hline S6 & & & & & & & & & & & 63.2 & 3.76 \\
\hline
\end{tabular}




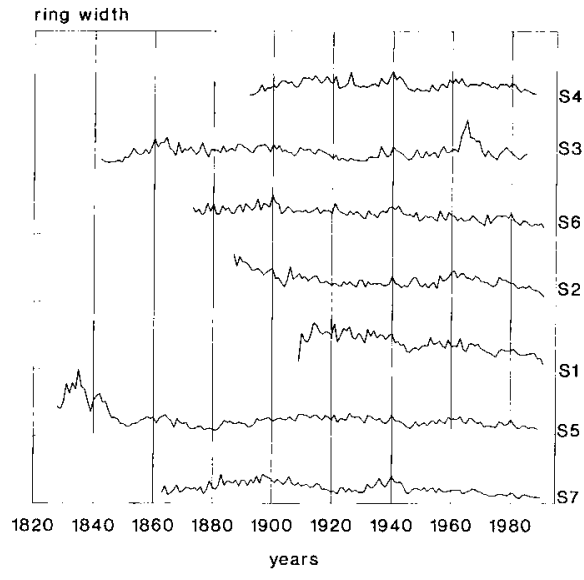

Fig 3. Site dendrochronological curves.

decreasing biological trend of growth. For the purposes of this analysis, however, growth-climate relationships are investigated on the pointer years which are present in both the raw data and the residuals.

\section{Growth-climate relationship}

Figure 5 shows the visual agreement between residuals and total mean annual precipitation and the mean annual temper- ature, both arranged from October of year $\mathrm{t}-1$ to September of year $\mathrm{t}$. There are many points of agreement between the mean residual curve and precipitation. The relationship is positive, so that when precipitation increases, a positive growth trend is registered in the rings and vice versa.

The relationship to temperature, which in this phase appears to be mainly inverse, is less obvious, however. Some examples worth mentioning are: 1964 negative pointer year which was dry and warm, and conversely, 1963 positive pointer year which was cold and rainy and subordinately 1956 which was not a very rainy year but a cold one. Furthermore, the minimum ring width and rainfall of 1949 must be mentioned. This type of coincidence, however, cannot always be found. In fact, 1941, 1960 and 1965 were expected to be pointer years, due to considerable rainfall, but this was not the case and 1941 even shows minimum ring width.

More details arise from response function analysis. The statistical significance of the global response function obtained with matrix P-TMAX is over $99 \%$ of statistical probability, and $81 \%$ of the residual variance can be explained by the climate. With the P-TMIN matrix statistic, probability is over $99.9 \%$, with $82 \%$ of residual variance explained by the climate. In figure 6 , the

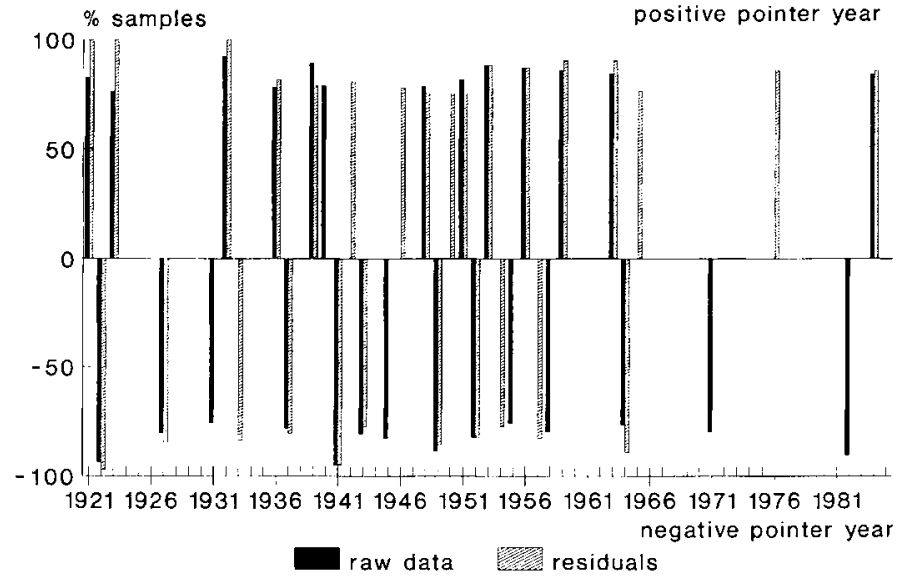

Fig 4. Determination of pointer years with at least $75 \%$ of growth trend agreement. 
Fig 5. Comparison between mean residual curve (MR) and annual mean precipitation (MP) and annual mean temperature (MT).
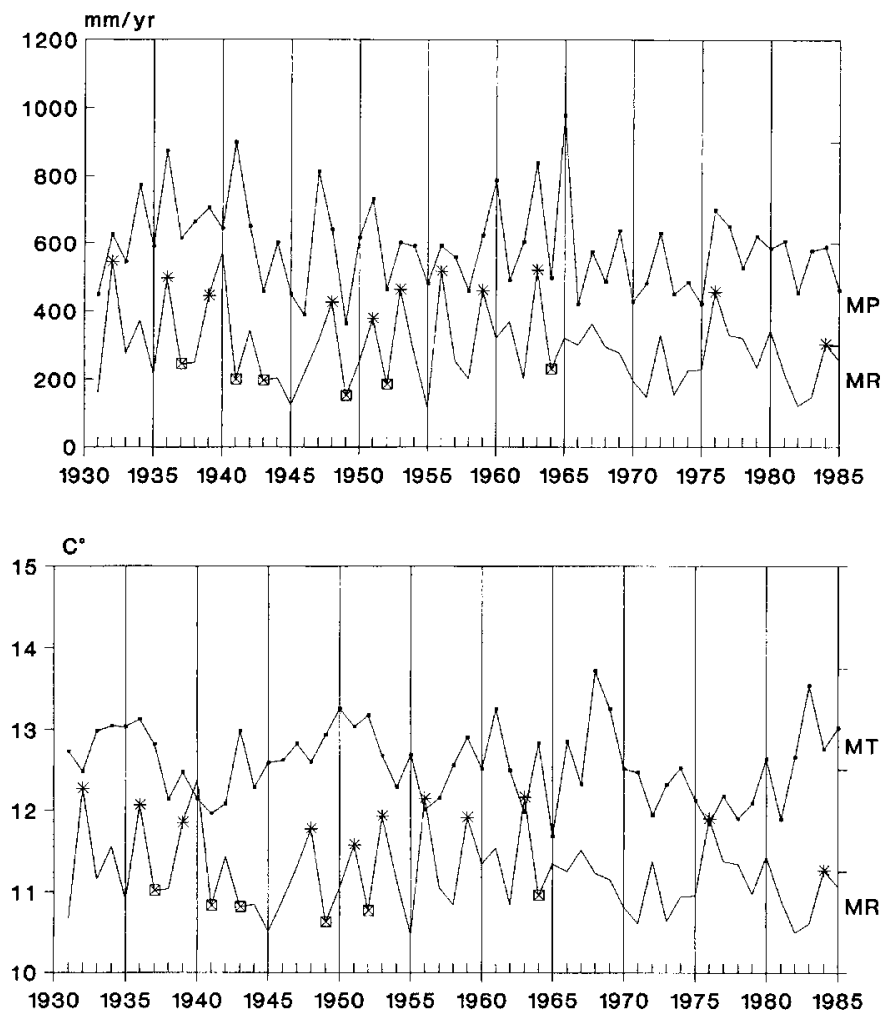

response function profile calculated on the mean climatic data and the mean residual curve and that calculated by averaging the monthly codes relative (Tessier and SerreBachet, 1990; Tessier et al, 1994) to each site, is shown. In both methods, the most significant codes (ie, the ratio between monthly partial autoregression coefficient and its standard deviation) are those concerning the rainfall of April, May and June of growth year t. From figure 6 , one could infer that November, December and January's precipitation also play an important role, but when using the second method, only the influence of November's precipitation is visible. Regarding temperature, June registered a significant signal.

Some conclusions may be drawn by comparing the two methods. In fact, the results obtained from the former method do not contrast with those of the latter in which, neverthless, the monthly codes registered are less significant.

The influence of these climatic parameters on tree physiology has been reported previously in other publications (Schirone and Romagnoli, 1990; Romagnoli, 1993; Martinelli et al, 1994) and comparisons can be made using results obtained with other species of the genus Quercus (cf Tessier, 1986, 1989; Bednarz and Ptak, 1990; Tessier and Serre-Bachet, 1990; Nola, 1991; Wazny and Eckstein, 1991; Santini et al, 1994; Tessier et al, 1994) especially with regard to the importance of spring and autumn precipitation on ring width.

Figure 7 shows the comparison between pointer years in the mean residual curve 


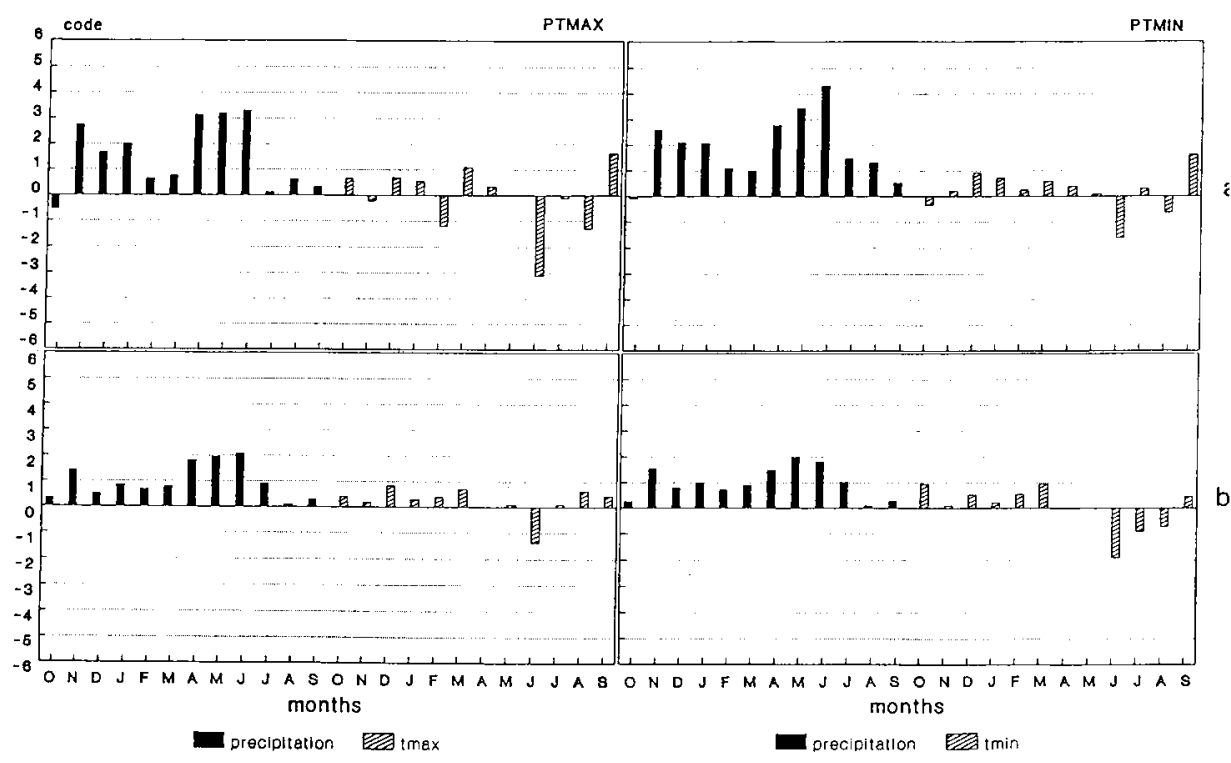

Fig 6. Response function profile calculated on the mean residual curve and the averaged climatic data (a), and the averaging of the monthly codes for each site (b). Monthly codes obtained with $P$ TMAX array and P-TMIN array. P-TMAX: precipitation-maximum temperature, P-TMIN: precipitation-minimum temperature, tmax: maximum temperature; tmin: minimum temperature.

and the monthly climatic parameters which resulted more limiting for growth.

\section{Image analysis}

Due to the restricted number of samples used, the results obtained may only be considered in order to evaluate the validity of the approach. Figure 8 shows that the first vessels (intervals 1 and 3 ) relative to years 1952 and 1954 are increased in size following the positive pointer years 1951 and 1953. However, some observations can be made within the ring regarding compliance with the formalities of passage from earlywood to latewood. Figure 8 does not reveal correlation between characteristic ring width and the standardized vessel diagram. In fact, profiles relative to years 1952 and 1953 appear more similar to each other than they do to years 1951 and 1953, which are both positive regarding width.

Figure 9 shows a comparison of the mean standardized vessel diagrams relative to the 5 years considered. Following examination of the total mean profile (fig 9), it may be evinced that the greatest variability concerns intervals 2, 3, 4 and 5 . This result depends on the greater or lesser development of latewood or of the entire ring, on the presence of more rows of vessels forming the porous ring and on the presence of intermediate size elements forming transition wood.

\section{DISCUSSION}

Response function analysis allowed us to determine the common macroclimatic factor which makes the dendrochronological curves 
Fig 7. Comparison between mean residual curve (MR) and the sum of April-MayJune precipitation (AMJP), inverse June maximum temperature (JTX).
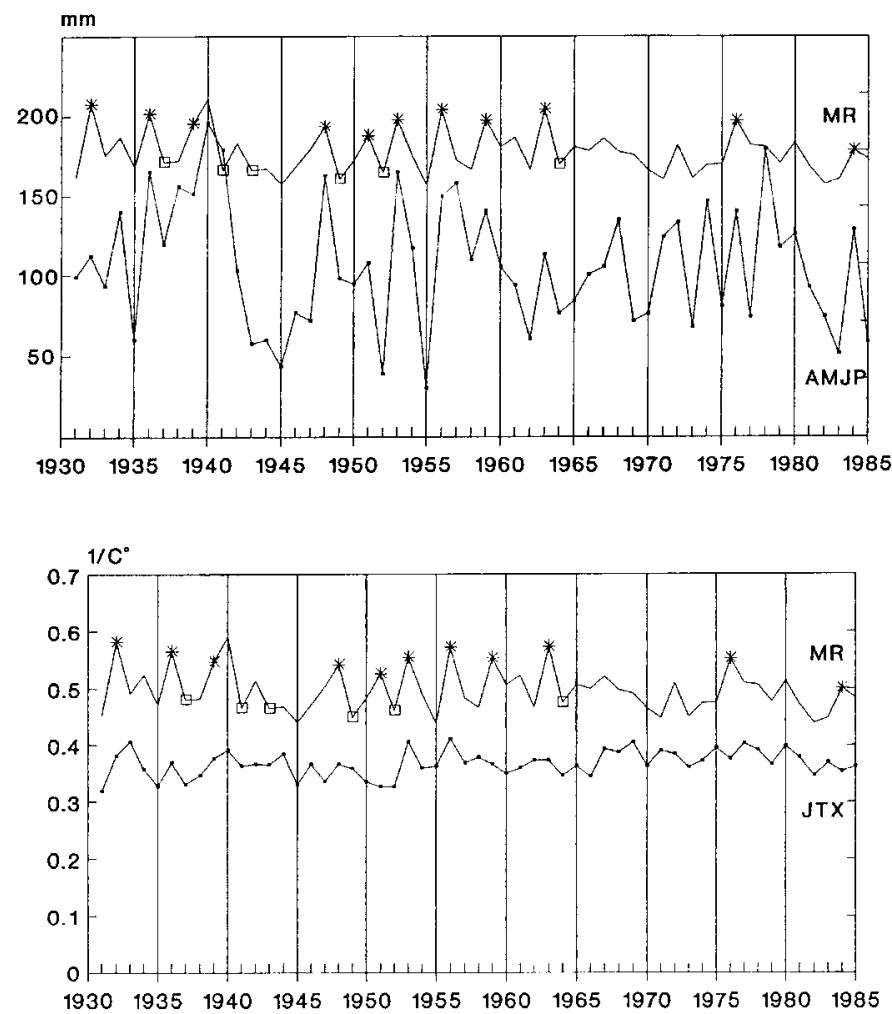

comparable with each other. A series of conclusions may be drawn from the methods of analysis employed for this research paper.

Extrapolation of the common climatic signal effected solely by means of macroscopic observation of ring widths proved difficult in the samples examined, due to strong human interaction in the area. Abrupt growth changes can often be ascribed to the silvicultural intervention which occurs frequently in this area; thus, growth trend analysis seems more appropriate under such circumstances.

Of the 17 pointer years, 13 show the same total annual precipitation trend, while 16 are in accord with the April, May and June precipitation trends and only 11 correspond to the inverse of the trend registered in the June temperatures.
As is widely accepted, pointer years relate not only to the mean climatic trend but often reflect extreme climatic (Schweingruber et al, 1990, 1991) or biotic events such as insect infestation (Pignatelli and Bleuler, 1988). However, the results of this research show the majority of pointer years as being explained from a climatic point of view, using mean climatic parameters.

The frost of 1929 and snowfall of 1965 , which are reflected in narrow rings in Turkey oak of the Gargano region (Corona, 1981/82) do not appear in the trees examined at present in the Latium region. This could be explained by the species' range of tolerance and by the fact that it grows in the optimum of its range and hence an extremely unfavourable climatic event might be counterbalanced by other environmental factors 


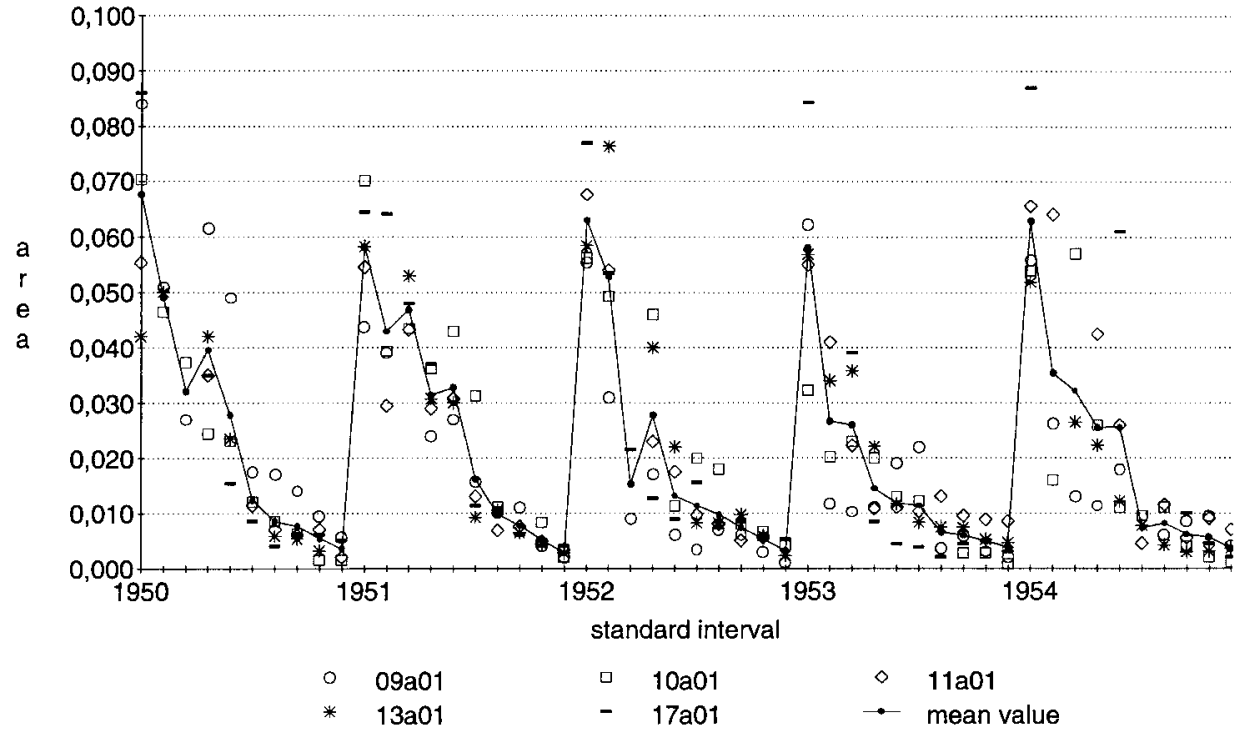

Fig 8. Standardized vessel area diagrams of five samples, with mean area values calculated on ten intervals for each year.

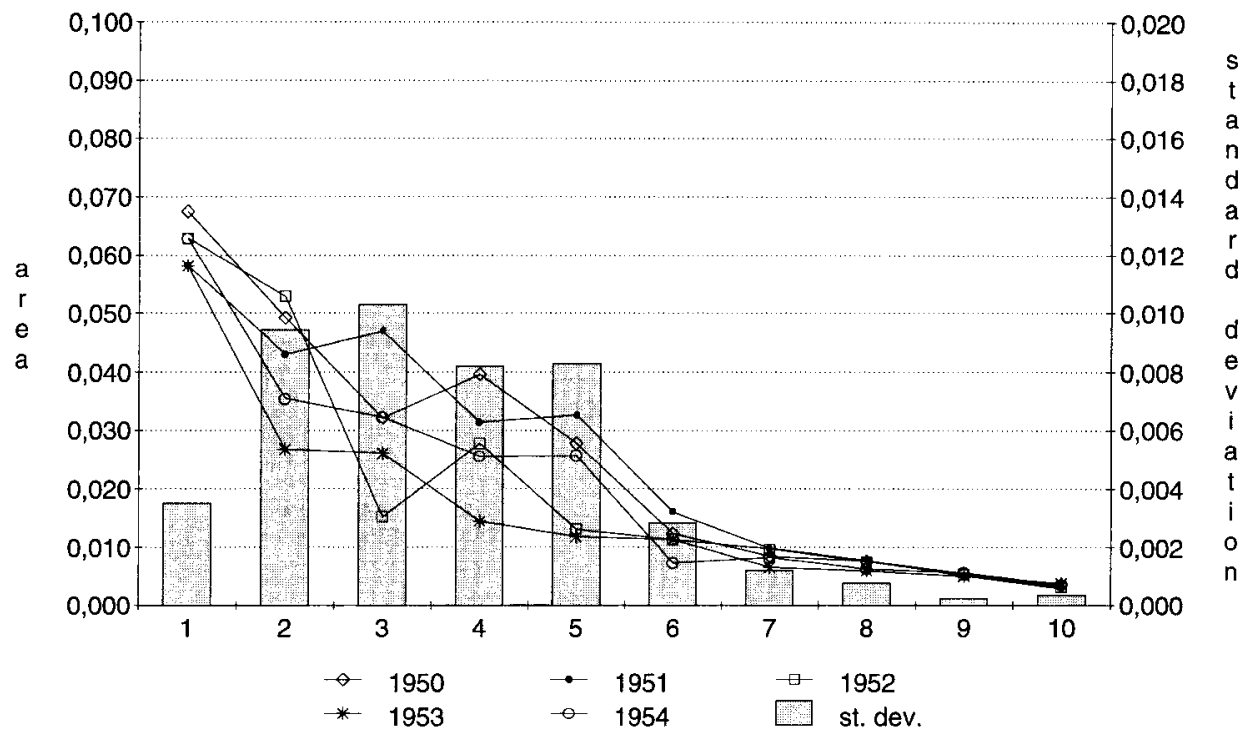

Fig 9. Comparison of the mean standardized vessel diagrams relative to the 5 years considered. Descriptive statistics of vessel area mean value for each interval. 
which act favourably. Moreover, different vegetative periods may make plants more sensitive to the effects of the late frosts.

As far as the possibility of relating anatomical parameters to environmental factors is concerned, the previous research effected studied oaks from the robur section. Besides studies confirming the relationship between morphometric parameters and environment (Eckstein and Frisse, 1979, 1982), there are those which demonstrate influence of ring width, age and genetic control on wood anatomy (cf Huber FH, 1994; Helinska-Raczkowska, 1994). Nevertheless, interactions among all these factors are complex and it is difficult to extract the influence of one single element. The method presented here for histologic representation confirms the complexity in anatomical analysis but might supply a new quantitative parameter (besides the classic mean diameter, vessel area, etc) for this type of investigation. Moreover, Turkey oak proves interesting study material also because it belongs to section cerris and has anatomical characteristics which differ from the species of the robur section.

\section{ACKNOWLEDGMENTS}

The authors thank Prof E Corona and Prof B Schirone for their advice. Our thanks also go to researchers in the Laboratoire de botanique historique et palinologie of Marseilles, who trained us to use many dendroclimatic methods.

Many thanks to A Parlante and $L$ Sandoletti who collected the samples, and to the Italian 'CFS' which has provided a lot of the material examined.

\section{REFERENCES}

Aniol RW (1983) Tree-ring analysis using Catras. Dendrochronologia 1, 45-54

Aniol RW (1987) A new device for computer assisted measurement of tree-ring widths. Dendrochronologia $5,135-141$
Babos K (1986) The sunspot activity cycle and the formation of the annual ring width in some wood species. Wood Fiber Sci 18, 76-83

Bednarz Z, Ptak J (1990) The influence of temperature and precipitation on ring-widths of oak (Quercus robur $\mathrm{L}$ ) in the Niepolomice forest near Cracow, Southern Poland. Tree Ring Bull 50, 2-10

Blasi C (1994) Fitoclimatologia del Lazio. Eds Università la Sapienza, Rome and Regione Lazio

Blasing TJ, Duvick DN, West DC (1981) Dendroclimatic calibration and verification using regionally averaged and single station precipitation data. Tree Ring Bull 41, 37-44

Chalabi MN, Serre-Bachet F (1981) Analyse dendroclimatologique de deux stations syriennes de Quercus cerris ssp pseudocerris. Ecologia Mediterranea $7,3-21$

Codipietro G (1994) L'analisi d'immagine in xilologia. I tracheidogrammi dell'abete rosso. Tesi di Dottorato, Università degli Studi della Tuscia, Viterbo, Italy

Corona E (1987) La Dendrocronologia in Italia: situazione e applicazioni. Informatore Botanico Italiano $19,67-76$

Corona E (1988) Aspetti tecnologici del cerro. Proc of "Prospettive di valorizzazione delle cerrete dellitalia Centro-Meridionale". Università degli Studi della Basilicata, Italy

Corona $E$ (1989) Significato dendrocronologico delle querce. Monti e Boschi 40, 6-8

Corona $P(1981 / 82)$ Caratteristiche tecnologiche del legno di cerro del Gargano. Tesi di Laurea, Università degli Studi di Firenze, Italy

Corona P, Romagnoli M, Torrini L (1995) Stem volume annual increments as dendroclimatic indicator for Turkey oak (Quercus cerris $L$ ) of Gargano region. Trees 10, 13-19

Eckstein D, Frisse E (1979) Environmental influences on the vessel size of Beech and Oak. IAWA Bull2/3, 36-37

Eckstein D, Frisse $E$ (1982) The influence of temperature and precipitation on vessel area and ring width of oak and beech. in: Climate from Tree Rings (MK Hughes, PM Kelly, JR Pilcher, VC La Marche, eds), Cambridge University Press, Cambridge

Gadbin L (1992) Intérêt du choix des carottes de sondage en dendroclimatologie. Dendrochronologia $10,29-40$

Guibal F (1987) Dendrochronology of oak in Britanny. Dendrochronologia 5, 69-77

Guiot J (1986) Arma techniques for modelling tree-ring response to climate and for reconstructing variations of paleoclimates. Ecological Modelling 33, 149-171

Guiot J (1990) Methods and Programs of Statistics for Paleoclimatology and Paleoecology (J Guiot, L Labeyrie, eds), PNEDC, Université d'Aix-Marseille, France 
Guiot J (1991) The bootstrapped response function. Tree Ring Bull 51, 39-42

Helinska-Raczkowska L (1994) Variation of vessel lumen diameter in radial direction as an indicator of the juvenile wood growth in oak (Quercus petraea Liebl). Ann Sci For 51, 283-290

Huber B, Giertz-Siebenlist V (1969) Unsere tausendjährige Eichen-Jahrringchronologie, durchschnittlich 57-(10-50) fach belegt. Sitz der Österr Akad Wiss Math -nat Kl , Abt I, 178, 37-42

Huber FH (1994) Déterminisme de la surface des vaisseaux du bois des chênes indigènes (Quercus robur L, Quercus petraea Liebl). Effet individuel, effet de l'appareil foliaire, des conditions climatiques et de l'âge de l'arbre. Ann Sci For 50, 509-524

Janous D, Bartak M (1991) Dendroclimatological study of Turkey oak (Quercus cerris L) at Bab (SW Slovakia). Ekologia 10, 31-42

Jaro Z, Tatraaljai E (1984) The annual growth of trees. Erdeszeti Kutatasok 76-77, 221-234

Martinelli N, Pignatelli O, Romagnoli M (1994) Primo contributo allo studio dendroclimatologico del cerro (Quercus cerris L) in Sicilia. Dendrochronologia 12, $61-76$

Messaoudene M (1989) Approche dendroclimatologique et productivité de Quercus afares (Pomel) et Quercus canariensis (Will) dans les massifs forestiers de l'Akfadou et de Beni-ghobri en Algérie. Thèse doctorat sciences, université d'Aix-Marseille, France

Nola P (1991) Primo approccio alla dendroclimatologia della quercia Quercus robur $L$ e Quercus petraea (Mattuschka) Liebl in Pianura Padana (Italia Settentrionale). Dendrochronologia 9, 71-94

Nola P (1992) Dendroecologia di Quercus robur L nella valle sublacuale del fiume Ticino. Tesi di Dottorato, Università di Pavia, Italy

Pignatelli O, Bleuler M (1988) Anni caratteristici come indicatori della tortrice grigia del Larice (Zeiraphera diniana Gn). Dendrochronologia 6, 163-170

Pilcher JR, Gray B (1982) The relationship between oak tree growth and climate in Britain. J Eco/ 41, 1-20

Pilcher JR, Baillie MGL, Hillam J, Pearson GW (1977) A long subfossil oak tree-ring chronology from the north of Ireland. New Phytol 79, 713-729

Pilcher JR, Baillie MGL, Schmidt B, Becker B (1984) A 72-year tree-ring chronology for Western Europe. Nature 312, 150-152
Raev 1, Georgiev N (1985) Long-term variations in the growth of Quercus cerris forests in the Strandzha mountains. Gorskostopanska-Nauka 22, 3-13

Romagnoli M (1993) Ricerche dendroclimatiche sul cerro del Lazio. Tesi di Dottorato, Università degli Studi della Tuscia, Viterbo, Italy

Santini A, Bottacci A, Gellini R (1994) Preliminary dendroecological survey on pedunculate oak (Quercus robur $L$ ) stands in Tuscany (Italy). Ann Sci For 51, 110

Schirone B, Romagnoli M (1990) Prime indagini dendroclimatologiche sul cerro dell'Alto Lazio. Proc "Effetti degli inquinanti atmosferici e del clima sugli ambienti naturali e sui manufattr', Bressanone, 25-26 October, 59-61

Schweingruber FH, Eckstein D, Serre-Bachet F, Bräker $O(1990)$ Identification, presentation, and interpretation of event years and pointer years in dendrochronology. Dendrochronologia 8, 9-38

Schweingruber FH, Wehrli U, Aelle-Rumo K, Aellen M (1991) Weiserjahre als Zeiger extremer Standortseinflusse. Schweiz Z Forstwes 142, 33-52

Serre-Bachet F, Tessier L, Loris K (1988) Mise en place et signification du cerne. Proc "Wood and Archeology: Bois et Archéologie". Pact, Acts of the Eur Symp, Louvain-la-Neuve, octobre 1987, 22, 13-22

Tessier L (1986) Dendroclimatologie et ecologie de Pinus silvestris $\mathrm{L}$ et Quercus pubescens Willd dans le sud-est de la France. Ecol Plantarum 7, 339-355

Tessier $L$ (1989) Spatio-temporal analysis of climate-tree ring relationship. New Phytol 11, 517-529

Tessier L, Serre-Bachet $F(1990)$ Chênes caducifolés en région méditerranéenne : relations cerne-climat. Ecol Medit 16, 209-221

Tessier L, Nola P, Serre-Bachet F (1994) Deciduous Quercus in the Mediterranean region: tree-ring/climate relationships. New Phytol 126, 355-367

Trénard Y, Duchateau JL (1985) Dendrochronologie du chêne dans la région de Paris. Dendrochronologia 3 , 9-22

Vaganov EA (1990) The tracheidogram method in treering analysis and its application. In: Methods of Dendrochronology (ER Cook, LA Kairiukstis, eds), Kluwer Academic Publisher, Dordrecht, the Netherlands, 63-76

Wazny T, Eckstein D (1991) The dendrochronological signal of oak (Quercus spp) in Poland. Dendrochronologia 9, 35-49 